\title{
Triangular migration diplomacy: the case of EU-Italian cooperation with Libya
}

\author{
Michela Ceccorulli* \\ Department of Political and Social Sciences, University of Bologna, Bologna, Italy \\ *Corresponding author. Email: michela.ceccorulli2@unibo.it
}

(Received 14 December 2020; revised 21 September 2021; accepted 23 September 2021; first published online 26 October 2021)

\begin{abstract}
Between 2016 and 2017, inflows along the central Mediterranean peaked, increasing pressures on the southern European border. Coordination with Libya to reduce departures has been possible thanks to the role played by Italy, backed by the Union. The diplomatic effort exhibited mainly through 2017 crafted a framework aimed at simultaneously ensuring Libya's interest in regaining full control of its sovereign prerogatives and addressing the EU's desire to reduce irregular inflows. This new framework is explored in this work through the lens of migration diplomacy with a double aim: to enrich the existing body of research by proposing a triangular analysis of migration diplomacy and to expand the literature on the external dimension of the Union's migration policy, by pointing out the political nature of migration relations and its critical aspects.
\end{abstract}

Keywords: EU; human smuggling; Italy; Libya; migration diplomacy

\section{Introduction}

Between 2016 and 2017, the central Mediterranean became the main transit zone for irregular entry into the European Union (EU), with Libya being the principal departure gate from Africa, and Italy the key landing dock. From 2014, inflows started to soar compared to previous years, reaching a peak in 2016 when more than 180,000 migrants arrived (Pradella and Rad, 2017). The number of deaths at sea also peaked, adding to the tragic list of drownings over the last 20 years.

Quite predictably, a central concern for Italy and the EU had become how to cope with the increasingly challenging situation of disembarkments from Libya flowing into Europe, mostly through Italy. The North African country's situation rendered it impracticable to replicate the strategy implemented with the EU-Turkey Statement of 2016, that is, sealing off the main corridor to the Union during the notorious 'migration crisis'. Some coordination with Libya has been possible, however. From 2014, the state had already become the focus of a new argument reiterated at different levels that the country's unity, stability, security and development were all being undermined by irregular immigration, and that policy towards Libya should reflect this. This posture became prominent through 2017 as key players crafted a new framework aimed at simultaneously ensuring Libya's interest in regaining full control of its sovereign prerogatives and addressing the EU's desire to reduce irregular inflows.

This new framework is explored in this work through the lens of migration diplomacy. Recent interest in this concept has visibly intensified: scholarship has started to examine its meaning and possible uses, while experts and analysts have underscored its growing applicability to states'

(C) The Author(s), 2021. Published by Cambridge University Press on behalf of the Società Italiana di Scienza Politica. This is an Open Access article, distributed under the terms of the Creative Commons Attribution licence (https://creativecommons.org/licenses/by/4.0/), which permits unrestricted re-use, distribution, and reproduction in any medium, provided the original work is properly cited. 
relations. The EU's increasing reliance on its foreign policy box to cope with migration challenges makes the concept of utmost relevance and the case under analysis appropriate for developing research along this line of enquiry.

Overall, this work makes two important contributions to the available literature. First, it provides original insights into the existent body of research on migration diplomacy, going beyond the classic two-level game (Adamson and Tsourapas, 2019) that is often supposed to exist in negotiations. Triangulating the EU's, Italy's and Libya's interactions in fact demonstrates that constraints are placed on migration diplomatic strategies (Tsourapas, 2017, 2379) not only by states' domestic constituencies [as often applies to liberal democracies (Greenhill, 2016)] but also by 'external' pressures, in this specific case those exerted simultaneously by the diplomatic game being played between Italy and the EU on migration. Second, it expands the literature on the external dimension of the Union's migration policy and related critical approaches, by pointing out the political nature of migration relations: assuming that the EU's (and Member States') strategies on migration are inexorably imposed on external actors implies neglecting the role migration currently plays in actors' interactions. Likewise, precisely because of the deplorable consequences of certain policies for migrants' fates, there is a vital need to carefully contextualize them in order to seek remedies.

The article proceeds as follows. It first introduces migration diplomacy as a concept, considering the previous disorganized scholarship and highlighting the contribution of recent works. Then, it details the stages that, on different levels, have seen migration diplomacy at work: by examining the compound relations between Italy, the EU and Libya that led to the hectic phase of deals between 2016 and 2017 in the field of migration, the case study adds original insights to the analysis of the concept, exploring the interplay between different negotiating tables and its consequences. A final section exposes the main criticisms of the diplomatic effort in relations with Libya. The conclusion briefly sums up the main findings.

\section{Migration in states' interactions}

As the EU's governance of migration has become entangled with its external action, a growing scholarship has devoted attention to the form and nature of such an occurrence, often in a critical way. The strand of research focussing on 'externalization dynamics' is now decades old (among others Boswell, 2003; Lavenex and Kunz, 2008) but by no means démodé, nourished by recent cooperation projects launched by the Union with third states (Collett and Ahad, 2017; Koch et al., 2018; Baldwin-Edwards and Lutterbeck, 2019). Significant contributions have shed light on the bias of this line of enquiry, albeit missing the 'political' aspect of the matter: the EU's actions do not occur in a vacuum but become part of a game being played between actors, often with different stakes (Pastore and Roman, 2020). The literature on 'conditionality' has somehow captured the relational nature of migration, mainly underscoring the paternalistic and neo-colonial dynamics at play. Relations between Italy and Libya seem to fit the case even beyond the Gaddafi's rule, confirming the argument of those scholars sustaining that neocolonialism is still largely at play in a dissimilar or exactly because of a different political and security context (Morone, 2017; Pradella and Cillo, 2020), where Italy's interests cross those of some actors claiming power in the country. However, which player truly gets the upper hand is not straightforward when migration is concerned (Greenhill, 2010, 2016; Pastore, 2017; Woollard, 2018).

Certainly, there is nothing new about 'negotiations' in foreign policy. For a long time now, an entrenched scholarship has analysed tactical issue-linkage as a bargaining game where compensations by one party are provided to persuade the target actor to cooperate (Haas, 1980; Kratochwil and Mansfield, 1994; Hampshire, 2016). This game has often been at play in the field of migration, from admission opportunities for citizens of specific states to irregular migrants' readmission, to name just a few issues. Going beyond tactical issue-linkage, where 
issues need not be conceptually bound, Betts (2011) has moved a step forward in bridging studies on international relations and migration: cross-issue persuasion traces a direct causal relationship between the issues being discussed, originating substantive issue-linkages and adding another layer of depth to negotiations. ${ }^{1}$

The potential of planned exchange on migration has not passed unnoticed; hence scholars have started to talk about the possible use of migration in diplomatic relations (Thiollett, 2011; İçduygu and Aksel, 2014). According to Greenhill (2016, 24), migrants and refugees have historically been used as 'foreign-policy bargaining chips', nicely said, or 'coercive weapons', truthfully, to manipulate a target. Still, the international relations literature seems to have neglected the relevance of the topic and the need for a systematic analysis of the processes at play (Tsourapas, 2017). That is, the potential for the strategic use of migration was captured, yet mainly explored in the context of other disciplines. The recent surge of migration into actors' foreign strategy and policy suggests that now more than ever, this field of research warrants specific consideration.

For all these reasons, re-energized consideration of 'migration diplomacy' is much welcome in both theoretical and analytical terms. Migration diplomacy as a concept holds the potential to make sense of how migration relations are built as part of actors' reciprocal interactions. In a recently published article, Adamson and Tsourapas (2019) introduce the concept as 'states' use of diplomatic tools, processes, and procedures to manage cross-border population mobility' (115-116), specifying that the expression applies to states' actions (but can be extended to international actors such as the EU) and refers to those migration policies which are part of diplomacy or foreign relations. According to the authors, the diplomatic use of cross-border mobility can promote the achievement of foreign policy aims, and diplomatic tools could be employed to achieve migration-related goals. Ultimately, this would be mostly determined by a country's 'position (or role)' in the migratory journey, despite the awkwardness of this distinction today. Recently, the literature has particularly emphasized the political strategies of states and specifically those dubbed 'transit' states, offering a new entry to the analysis of the interaction between migration and influence. Assessing the case of Niger, Frowd (2020) maintains that the multilevel and multi-layered 'production' of the state as a transit area operated by international interveners, Nigerian actors, sub-state, non-state and international organizations has a clear impact on security practices applied in that context; it also has the effect of placing migration close to crossnational crime, while promoting a blending of civilian-security capacity building and migration management. Adamson and Tsourapas' reference to the EU-Turkey Statement of 2016 and related provocatory stances adopted to show Turkey's leverage on the issue convincingly demonstrates the pertinence of the concept (see also Demiryontar, 2020). In a similar way, Düvell (2017) argues that power relations between Turkey and the EU have largely been reconfigured since the migration crisis.

The concept is increasingly being applied among scholars producing original research. Some works have investigated the influence of geographical position and diplomatic relations on domestic migration plans, as in the case of Morocco and Turkey's policies launched in 2013 (Fernández-Molina and De Larramendi, 2020; Norman, 2020). Some others have investigated the connection between states' migration diplomacy and foreign and security policy objectives, illustrated, for example, by cooperation between the Union and Jordan since the start of the Syrian crisis in 2011 (Seeberg, 2020) and Egypt's cooperative stance on migration as evidenced by the 2016 anti-smuggling law (Völkel, 2020). But IR pundits have yet to explore the most salient features and dynamics currently at play in states' interactions on migration.

Therefore, focussing on the concrete aspects of the discipline might be an invitation for further reflection. The distinction between cooperative and coercive migration diplomacy (Tsourapas,

\footnotetext{
${ }^{1}$ The environment-migration and the development-migration nexuses are two leading examples of emerging dominant debates exemplifying substantive issue-linkages (Betts 2010).
} 
2017) is germane here: in the first case, the diplomatic game involving migration is expected to produce advantages for the actors engaged in negotiations, while in the second case, one actor's will may be imposed on another, reducing the strategic options of the subdued. According to Tsourapas $(2017,2368)$, Muammar Gaddafi made use of both cooperative and coercive migration diplomacy between 1969 and 2011 in relations between Libya and other African states, and primarily showed a coercive mode with the EU and EU Member States, Italy first and foremost (Paoletti, 2010; Ceccorulli, 2014) to achieve different sets of goals. Exploring the case of the Syrian refugee crisis, Tsourapas (2019) infers that the choice between a 'blackmailing' or a 'backscratching' strategy can be adopted by a state hosting refugees according to the numbers of refugees hosted and its geostrategic location, confirming yet again the role played by a state's (self) positioning as a 'transit' country.

In contrast, this work highlights how the diplomatic use of migration has recently adopted the narrative of a cooperative game: linking Libya's stabilization with the fight against human smugglers had the potential to achieve both Italy's and the EU's objective of curtailing irregular arrivals (migration as an end) and the aim of Libya's Government of National Accord (GNA), to be internationally recognized and supported in regaining its damaged statehood (migration as a means). Irregular immigration - described as a tool in the hands of smugglers - was cast as a threat to the political existence of Libya as a state with sovereign prerogatives and development potential, risking both the country's unity and migrants' lives. Despite the problems with this argument, the triangular interplay pivoting around migration is worth examining.

\section{Methodology and case-selection}

Europe has a vested interest in seeking cooperation with Libya to stem irregular mobility across the Mediterranean. Irregular arrivals have posed particular challenges for the EU as it seeks to balance and address a range of stakes. Indeed, attempts at cooperation in order to cut down on arrivals are not new; but they have hardly worked in the past. More profitable attempts have been conducted at the state-to-state level (Cassarino, 2010), mostly informally (Cassarino, 2018), and in a way that builds on specific pre-existing relations between countries. Where 'success' has been achieved, however, flows have generally been reduced only temporarily, and were more often simply diverted elsewhere, raising concerns over the treatment of migrants 'contained' in origin or transit countries (Coleman, 2009; Carrera, 2016; Yildiz, 2016; Collett and Ahad, 2017).

Italian-Libyan relations in the field of migration are characterized by a history of success and setbacks. Tied by a colonial past, by geographical proximity and by reciprocal and substantial economic interests, the two countries have traditionally treated migration as another dossier in their strategic interactions. Whereas Italy had long-established and constant contacts with the north African country, the EU could hardly exert any leverage on the state. For this specific reason, looking at the way the Italy-EU-Libya diplomatic game on migration has recently developed is worth exploring as a case study. This heuristic exercise is relevant per se in that Libya has been constantly 'co-produced' as a 'transit country' (Frowd, 2020), even though it is in fact a destination for most migrants heading there (Pradella and Cillo, 2020). Indeed, it has recently been the main corridor for irregular immigrants into the Union and fertile ground for a myriad of other dreadful transnational challenges spuriously related to migration. The analysis also aims to uncover aspects that previous research has left untouched. Certainly, the diplomatic game being played between Italy and the Union has been highly relevant both in terms of the content and pace of diplomatic interaction between Italy and Libya.

The article employs a methodology of process tracing of documents and public statements to uncover the arguments of policy-makers and how these have played out in policy decisions (Beach, 2017). Both EU and Italian primary sources are considered together with relevant speeches and interviews. As a compendium, the existing academic literature as a secondary source 
is explored. EU documents from 2014 and 2017 are analysed, to appreciate the urgency of addressing human smuggling and to support Italy's initiative to cope. In contrast, Italy is mainly observed throughout 2017, as this is the year when contacts reached their peak thanks to new activism and frantic contacts with the Union to defuse pressures on the southern European border.

\section{Migration diplomacy at play: capacity-building to restore Libya's sovereignty}

Over the last several years, the Mediterranean region has been deeply troubled by ongoing political and security instability in Libya. This began with the mass uprisings of 2011, brutally repressed by Libya's ruler, Muammar Gaddafi. After two United Nations (UN) resolutions in two months (no 1970 and 1973) aimed at protecting the civilian population, NATO took on the leadership of an already assembled multinational force and launched the military operation Unified Protector (Engelbrekt et al., 2013; Kuperman, 2013). Italy, which was initially ambivalent with regard to the operation for fear of compromising agreements reached with Libya's leader especially in 2008, then engaged in full force, its military effort being the fourth after the US, France and the UK's (Ceccorulli and Coticchia, 2015). The operation eventually led to the toppling and death of Gaddafi, according to some the real objective of the international coalition (Pradella and Rad, 2017), only to leave unresolved many issues related to the subsequent stability and unity of the country. In particular, as emphasized by many scholars, fragmentation, caused by many groups quickly shifting alliances, merging, dividing and rebranding themselves, has been a key feature of the internal struggle for political succession (Pack, 2019). As acknowledged by the Union, there was a clear failure to adequately address disarmament and reconciliation (European External Action Service, 2014) in a country that had lost most of its sovereignty prerogatives. This security vacuum also intersected with significant regional turmoil, security challenges and mounting external intrusions by states exhibiting divergent aims. Restoring Libya's sovereignty and capacity to control its borders thus became an urgent priority for the entire international community - especially for the EU, since Libya was at the moment the main departure gate for migrants seeking to enter Europe.

Starting in 2014, hostilities between different factions in the country resumed over the political, economic and military control of the state and different visions of the country's future emerged (European External Action Service, 2014). Given its geographical proximity to Europe - but also its centrality to fundamental European interests, such as hydrocarbons - the EU felt the need to confront the looming instability in the country. In 2014, the External Service of the EU was tasked with preparing the Political Framework for a Crisis Approach (PFCA) to lay out the strategic priorities in this area. First among these priorities was to support the work of the UN in trying to advance a political dialogue in the country with the aim of ending hostilities. The resumption of conflict in 2014 also forced the EUBAM Libya mission to slow its pace of activity and decrease personnel, and to shift the headquarters of its security support and border management operations at Libya's main borders (air, land and sea) to neighbouring Tunisia, given the impossibility of running operations in Libya itself.

After 2014, flows started to visibly increase in the central Mediterranean and concurrently also the number of persons dying in the attempt to reach the EU. This clearly signalled the perilous nature of that transit corridor, as well as the poor travelling conditions suffered by migrants mostly subject to smuggling operations. In April 2015, when more than 800 migrants capsized and died off the coast of Libya, the international community was compelled to show resolve, pointing the finger at the smugglers, who had been free to operate because of Libya's evident lack of capacity to exert effective control of its territory, especially given its attenuated security apparatus. $^{2}$ Against this background, the UN Security Council passed Resolution 2240 (2015)

\footnotetext{
${ }^{2}$ For an overview of the type, nature and migration trends in Libya, see Darme and Benattia (2017).
} 
on 9 October 2015, authorising Member States to intercept (and eventually seize) vessels at sea off the Libyan coast suspected of migrant smuggling. Thanks to Resolution 2240, the EU was able to pass to the second phase of a Common Security and Defence Policy (CSDP) operation launched during the summer, EUNAVFOR MED Operation Sophia.

Already in May 2015, the EU's former High Representative for Foreign and Security Affairs Federica Mogherini had informed the UN Security Council of the situation in the Mediterranean and the intention to set up a CSDP naval operation with UN backing (European Council, 2015a, 5). The operation, approved by the European Council on 18 May 2015, was conceived of to prevent more people from dying at sea, a human tragedy pinned directly on smuggling activities across the central Mediterranean. Actions to prevent deaths at sea by cutting off smuggling activities had to go in the direction of strengthening the EU's presence at sea, specifically to disrupt the business model of smugglers in the southern part of the central Mediterranean.

Hence the attention given to smuggling and to the need to improve Libya's capacities to curb the phenomenon became evident. These aspects could only be ensured by the parallel strengthening of the country's sovereign prerogatives. However, operation EUNAVFORMED Sophia was only one of many migration-related initiatives undertaken in 2015.

Both because a newly elected Commission had upgraded migration as a top priority for the EU and because of the heightening of the so-called migration crisis, new emphasis was placed on framing an overall plan in the field of migration. The Agenda on Migration (European Commission, 2015a) articulated a new medium to long-term strategy around the fight against human smuggling, strengthening relations with third states, and improving prospects for citizens in countries of origin and transit over the medium term. Specifically concerning Libya, which at that time had not yet come to the centre of the political debate, it was affirmed that such initiatives had to be related to the political objective of promoting stability in the country and supporting UN initiatives. The review of the European Neighbourhood policy in November 2015 (European Commission, 2015b) introduced a strong focus on cooperation on regular and irregular migration with partner states and on improving the security of these third states, the latter being cast in terms of stabilization and 'resilience' (12-13).

More than on any other occasion, this overall acknowledgement came to the fore during the November 2015 Valletta Summit, which was preceded by a critical decision in October 2015 namely, to establish a 'European Union Emergency Trust Fund for stability and to address the root causes of irregular migration and displaced persons in Africa' (European Commission, 2015c). The main aim of this fund has been to foster resilience, economic opportunities, security and development to address the causes of destabilization, forced displacement and irregular migration. The Fund thus entailed a financial commitment by the EU, complementing traditional development instruments, for the Sahel region, Lake Chad, the Horn of Africa and North Africa (Libya included). At the Joint Summit on Migration held in Valetta on 11-12 November, EU and African leaders issued a political declaration recognising the priority of jointly managing migration (European Council, 2015b, 2). The declaration prioritized the need to protect migrants - both at sea and in the desert - from abuse, exploitation and death. Supporting resilience and self-reliance, boosting socio-economic development, improving asylum perspectives, combating irregular immigration, human smuggling and trafficking and building capacity on border management and the return and reintegration of irregular immigrants were key points. In order to achieve some of these objectives, the EU emergency Trust Fund was cast as a vital instrument.

In talks with African countries, the emphasis put on the exploitation and deaths of migrants was evident, as was the need to confront these problems through a capacity-building approach aimed at reducing the outflow of irregular immigrants. This would have proved particularly relevant in the case of Libya, but the political situation there prevented any discussion from moving forward. For this reason, the adoption of UN Security Council Resolution 2259 (2015) welcoming the signing of a Libyan Political Agreement and recognising the GNA as the sole legitimate 
government of Libya was crucial. Particularly relevant was the UN invitation to Member States to urgently respond to requests for assistance from the Libyan government. The resolution also invited Member States to share information with the new government on smuggling and trafficking activities in Libyan territorial waters and along Libya's coasts and to help it assist migrants rescued at sea.

The approach of addressing migrant deaths by dealing with the smuggling networks was thus well established by the end of 2015. That was particularly so because of a clear association between Libya's instability and the smuggling phenomenon, and, consequently with deaths at sea and in the desert. However, aside from EU humanitarian aid disbursed after 2014 to address the consequences of the conflict and efforts to extend some programmes of the Trust Fund supporting the United Nations High Commiss ioner for Refugees (UNHCR) and the International Organization for Migration (IOM), throughout 2016 no measures for stricter cooperation with Libya were concretely advanced (European Commission, 2016). Libya's fragmented political situation and its security problems were well documented by the EU, which defined border security and migration management as being 'in complete disarray and in dire need of institutional and legal reform' (European Council, 2017a, 35). Further concern was expressed about migrants' detention conditions and the existence of many informal centres, given that the UNHCR could not access these sites (European Council, 2017a, 37; UN Support Mission, 2016). Libya's traditional place at the crossroads of the old trans-Saharan trade and smuggling routes was referred to, against a backdrop of gangs and armed groups operating at liberty, trading in migrants, weapons, drugs and engaging in other illicit activities thanks to the absence of effective police and border control (UN Support Mission, 2016, 54).

Some signs indicating a strong commitment by the EU were indeed present, such as the extension of EUNAVFOR MED's mission to include capacity-building tasks and the training of the Libyan coast guard, and the launch of a high-level dialogue with Libya's government, led by the High Representative at the beginning of 2016 (European Commission, 2016, 2). Also, in August 2016, the Council extended the duration of the EUBAM Libya mission and enlarged its potential tasks (pending a request from Libya) (European Council, 2016). Nevertheless, the acknowledgement that single Member States, Italy foremost, were better positioned to build more thorough cooperation with Libya was reiterated (European Commission, 2016).

It was only at the beginning of 2017 that efforts to cooperate with Libya achieved concrete results thanks to the Italian role. This initiative consolidated the existing narrative on smuggling, backed by financial support from the EU (but not always of single Member States).

\section{Italy's diplomatic game with Libya}

Italy assumed a distinct role in the central Mediterranean from 2013 on when the country launched a unilateral, humanitarian military operation, Mare Nostrum, after the drowning of many migrants off Lampedusa.

Italy boasts a long history of intense relations with Libya. It was Italy back in the '90s that restarted dialogue with an internationally isolated Libya and its decisive leadership was also crucial in restarting closer cooperation in 2017. Mainly thanks to the new Minister of the Interior, Marco Minniti, new initiatives were proposed. However, European support was vital in advancing the strategy Minniti had in mind. This was a comprehensive 'method' based on stabilization, political reconciliation and the opening of economic opportunities for the local population to weaken and impair the networks of organized crime and, hence, reduce arrivals in the EU. Also, according to Minniti, work had to be done to improve the human rights of migrants and asylum seekers present in Libya.

Against this backdrop, 2017 can rightly be called 'the year of the central Mediterranean', for the number of initiatives undertaken concerning the region. On 14 January 2017, Italy approved the implementation of a mission aimed at training the Libyan coastguard by the Guardia di 
Finanza (Italy's financial crimes police) and maintaining naval assets donated before the civil war. The mission was not new but had been suspended for security reasons - indeed, it implemented an agreement signed between the two countries in 2007, on the joint patrolling of Libyan territorial waters backed up by a later protocol in 2009 . The mission could now be cast as a legitimate effort not only to prevent irregular immigration (its original objective) but also to contribute to stabilizing the country.

For its part, the EU inaugurated a new phase in relations with Libya. On 25 January 2017 (in coordination with Italy), it delivered a document wholly dedicated to the central Mediterranean (European Commission, 2017a, 1). The document clearly put Libya at centre stage. It made clear that smugglers and traffickers were the greatest beneficiaries of the instability looming large in the country and the country's weak capacity in territorial and border control. It underlined that those criminal networks were further contributing to the country's instability merely by existing and by endangering migrants' rights. Promoting the stabilization of the country would thus significantly curtail smugglers' room for manoeuvre and avoid migrants' deaths at sea, while clearly reducing inflows into Europe. An additional point was to insist on strengthening Libya's control capacities: given an increased presence at sea (also of search and rescue activities) close to Libyan waters, smugglers had changed strategy, loading migrants in completely unsafe vessels, and counting on those vessels being rescued close to or in Libyan waters. Hence, training the coastguard would increase the possibility of saving migrants in Libyan waters but also of intercepting smugglers before they could attempt dangerous enterprises (European Commission, 2017a, 6). While the EU would contribute to such capacity-building with all the efforts at its disposal (EUNAVFOR MED Sophia and EUBAM Libya), it was clearly stated that Member States had a significant role to play (European Commission, 2017b, 3).

Alongside the emphasis on capacity-building in both northern and southern Libya, the document recognized the need for a comprehensive strategy for the country, aimed at improving human rights conditions, ${ }^{3}$ socio-economic development, and actively engaging Libyan municipalities to increase ownership throughout the process. These efforts were intended as an attempt to diminish the causes of irregular emigration and thus the profit-making opportunities for smugglers. Coordination between Italy and the EU was facilitated by the 2 February 2017 issue of a Memorandum of Understanding (MOU) between Libya and Italy (Governo Italiano, 2017a). In recalling the cultural and historical linkages between the two countries - as well as the existing agreements, such as the 2008 Treaty of Friendship, Partnership and Cooperation the parties committed to collective efforts to confront the problem of irregular arrivals in Italy and its consequences, and fight terrorism, smuggling, trafficking and contraband. ${ }^{4}$ The MOU was followed by a set of initiatives taken over the next months. Meanwhile, in full support of both the central Mediterranean strategy and the MOU, the European Council's Malta Declaration was announced just a day after the Italian initiative (European Council, 2017b).

Italian initiatives during 2017 included the creation of a Contact Group on the Central Mediterranean route, which first met on 19 March (Ministero dell'Interno, 2017a). Discussions with engaged ministers from Europe and north Africa (Italy, Austria, France, Germany, Tunisia, Libya, Malta, Slovenia, Switzerland) mainly centred on tackling the smugglers' business model - the criminal gangs reported to being the only ones profiting from irregular migrant flows. The number of deaths at sea in 2016 was declared to be unacceptable, as was the unknown number of persons dying in the desert (Central Mediterranean Contact Group, 2017a).

\footnotetext{
${ }^{3}$ In this respect, a programme had already been adopted in December 2016 under the EU Emergency Trust Fund to provide assistance at disembarkation points and in centres and to assist migrants to return to their origin countries (European Commission, 2017b, 10).

${ }^{4}$ As recalled by Minister Minniti, the conditions visible at the time of Gaddafi in Libyan centres had to be absolutely prevented. Thus, the return of some international organizations, such as the IOM and the UNHCR, to Libya had to be applauded (Cazzullo, 2017).
} 
According to Minister Minniti, stabilizing Libya and fighting smugglers were two faces of the same coin (Ministero dell'Interno, 2017b). The training of the Libyan coastguard and the restitution on behalf of Italy of 10 patrol vessels by mid-May 2017 would contribute to empowering the Libyan coastguard and would advance the objective of intercepting boats in Libyan territorial waters and bringing them back to Libyan ports. Only shared responsibility, it was reported in the final declaration, could ensure success (Central Mediterranean Contact Group, 2017a). The idea of a comprehensive strategy aimed at tackling smugglers, however, had to devote attention to Libya's northern coasts as much as to the southern border, in full cooperation with neighbouring actors. On 31 March 2017, Minister Minniti played guarantor (thanks to a major diplomatic effort) to a peace agreement among three tribes of the southwestern region of Fezzan: the Tuareg, the Suleyman and the Tebu (Longo, 2017). Pacification was considered fundamental for addressing smuggling activities and for countering the threat represented by terrorism. It was also cast as crucial for expanding development opportunities as an alternative to criminal activities. Simultaneously, the patrolling of Libya's southern border contributed to the effort of reducing irregular inflows into Europe.

At the European level, efforts were made to support Italy's initiatives. Through a programme funded by the EU Emergency Trust Fund for Africa, $€ 90$ million was dedicated to addressing the socio-economic situation of migrants and refugees in Libya (where their irregular status is criminalized) but also that of the local host communities, thus 'strengthening resilience of local governance structures' (European Commission, 2017c, 1). Another objective was to train local authorities on migration-control-related tasks, thereby safeguarding a rights-based approach to migration (European Commission, 2017b). Projects by the Italian energy company, Ente Nazionale Idrocarburi (ENI), were financed in this direction. ${ }^{5}$ On 4 May 2017, the Commission delivered a document on 'a renewed impetus of the Africa-EU partnership' recognising the centrality of shared partnership in facing up to common challenges (European Commission, 2017c). Shared partnership, ownership and self-reliance were said to be key to adopting a 'resilience approach to migration' (European External Action Service, 2017a, 10).

Notwithstanding these joint efforts, some Member States were still reluctant to allocate the necessary funds to fully support actions in Libya under the Trust Fund (European Commission, 2017d). Moreover, with inflows soaring during the summer months, Italy urgently asked for a revision of disembarkation rules. Thus, on 30 June, Minniti addressed a letter to European authorities, reporting on the unsustainability of the situation. Subsequently, a revision of disembarkation rules was proposed to both France and Germany (2 July), and to FRONTEX through a formal letter (4 July), in the hope of a more shared effort within Operation Triton. For its part, the Commission presented an Action Plan for immediate measures to support Italy (European Commission, 2017d), in preparation for the 6-7 July informal meeting of Ministers of Justice and Home Affairs in Tallinn. The Commission Action Plan asked for more coordination in search and rescue activities in the central Mediterranean and approved an Italian code of conduct for NGOs (European Commission, 2017d, 1). ${ }^{6}$ It also called for an acceleration of the Libyan coast guard and land authorities' capacity-building efforts, also through the approval of a plan jointly envisaged by the Commission and Italy, for $€ 46$ million, to be financed under the Trust Fund. ${ }^{7}$ However, the informal meeting in Tallinn did not bring about the kind of support solicited by Italy for the 'regionalization' of rescue operations.

Italy's diplomatic efforts with Libya did not stop, but rather took on greater momentum in the face of Member States' lack of solidarity. On 13 July 2017, Minister Minniti met with Libyan

\footnotetext{
${ }^{5}$ The programme aimed, among other things, to address migrant reintegration in origin countries in coordination with the IOM (thus absorbing the December 2016 programme).

${ }^{6}$ For a critical analysis, see Cusumano (2017).

${ }^{7}$ This multi-year programme was to enhance border surveillance in Libya both in the north and south of the country. Mostly funded by the Trust Fund, it also received funds from the Italian government (€2.2 million) and the EU Internal Security Fund (European Commission 2017e).
} 
mayors from the coast and the southern border to define possible lines of intervention (Ludovico, 2017a). Minniti's speech in Tripoli on 'freeing the country from the plague of human smuggling and opening up new future opportunities for children' was extensively broadcast and local representatives arrived at the meeting with detailed development projects in hand (Ludovico, 2017a). As reported by the Minister, 'it has not been easy to break the sound-wall, but we finally did it' (Ministero dell'Interno, 2017a). The overall process had been started, Minniti argued, through liaison with the Sarraj government, ${ }^{8}$ with an agreement to develop a brand-new coast guard, unknown to the country until that moment (Ministero dell'Interno, 2017a). Cooperation was nurtured by the Libyan government's formal request for a more proactive role for Italy in the fight against smuggling (Ludovico, 2017b). Concretely, the request (the second after a first one on 23 July) was for a naval military presence on the Libyan coast. The request was approved by Italy on 2 August 2017 (Senato della Repubblica, 2017) and relied on vessel units of Mare Sicuro, a mission already present in the Mediterranean since 2015. The objectives of this ongoing mission included protecting ENI's oil and gas platforms off the Libyan coast as well as protecting merchant vessels and preventing terrorism (Ceccorulli and Coticchia, 2020). ${ }^{9}$ Given Libya's specific request, the new mission was intended to comply with UN Resolutions soliciting capacitybuilding and assistance.

Meanwhile, on 24 July 2017, the second meeting of the Contact Group on the Central Mediterranean was convened in Tunis (Central Mediterranean Contact Group, 2017b). ${ }^{10}$ Discussions centred on coordination efforts to fight the smuggling of migrants through capacitybuilding but also brought to the fore the issue of enhanced legal migration. Another meeting was held on 28 August between France, Italy, Germany and Spain together with Chad, Niger and Libya (Governo Italiano, 2017b). Concerning Libya, dialogue centred on fighting migrant smuggling through improved control capacities to save lives, accelerating migrants' protection through voluntary returns, and helping to establish alternatives to smuggling in local communities. In July and August 2017, there was an impressive drop in arrivals in Italy: while 23,000 migrants were recorded as landing in both May and June, the figures in August were not even 4000 (five times less than August 2016) despite the season, and remained below 6500 for the rest of the year (Table 1).

The publication in November 2017 of an exclusive report by CNN showing migrants being sold as slaves by smugglers in Libya strengthened the argument advanced by Italy and the EU on the criminal role of these actors and echoed loudly among African citizens (Elbagir et al., 2017). The President of the African Union (AU), Ipha Conde, and High Commissioner Mogherini swiftly and strongly condemned human smuggling and trafficking and reiterated their commitment to helping Libya tackle that challenge. The GNA declared it was ready to take up the challenge but also required the international community's support. That event produced an effect on the content of the AU-EU Summit (the fifth among the partners) held in Abidjan, Côte d'Ivoire in late November, placing at the forefront the challenge of ending the practice of slavery and improving migrants' conditions (European Council, 2017c). To facilitate the task of 'saving and protecting migrants' lives along the route' (European Council, 2017c), an AU-EU-UN Task Force was created, building on the programme already running under the EU Trust Fund in collaboration with the IOM to improve efforts for voluntary return and the resettlement of those in need. ${ }^{11}$

\footnotetext{
${ }^{8}$ Contacts were however established also with General Haftar, a necessary step according to Minister Minniti, in a process of national reconciliation (Cazzullo 2017).

${ }^{9}$ See also https://www.marina.difesa.it/cosa-facciamo/per-la-difesa-sicurezza/operazioni-in-corso/Pagine/MareSicuro.aspx

${ }^{10} \mathrm{~A}$ third one was held in Bern on 13 November 2017.

${ }^{11}$ The acceleration of the voluntary return programme was visible between November and December 2017, when 3000 migrants were assisted in returning (EEAS 2017b).
} 
Table 1. Landings in Italy in 2016 and 2017

\begin{tabular}{lll}
\hline & Landings 2016 & Landings 2017 \\
\hline January & 5273 & 4468 \\
February & 3828 & 8971 \\
March & 9676 & 10853 \\
April & 9149 & 12943 \\
May & 19957 & 22993 \\
June & 22339 & 23526 \\
July & 23552 & 11461 \\
August & 21294 & 3920 \\
September & 16975 & 6282 \\
October & 27384 & 5984 \\
November & 13581 & 5641 \\
December & 8428 & 2268 \\
\hline
\end{tabular}

Source: Dipartimento Libertà Civili e Immigrazione (2017) Cruscotto statistico giornaliero 31/12/2017. Ministero dell'Interno, http://www. libertaciviliimmigrazione.dlci.interno.gov.it/sites/default/files/allegati/cruscotto_statistico_giornaliero_31-12-2017.pdf

\section{Migration diplomacy: critical observations}

As just seen, Italy's intensified engagement in the southern Mediterranean during the summer months, to the point of a military deployment in Libyan waters, coincided with a significant drop in inflows of irregular immigrants. However, concurrent events could have also been decisive in curbing flows towards Italy: intra-Libyan struggles leading to instability may have rendered departures difficult to organize or, for detractors of NGO search and rescue activities, the halt in arrivals may well have been determined by their reduced presence in the Mediterranean after the establishment of the Code of Conduct. Some authors specifically point to the co-optation of militias involved in human smuggling as the reason for the sudden drop in arrivals (Maggie, 2017; Micallef and Reitano, 2017). Hence the change in the powerful role of the few militia controlling human smuggling at that moment had led to a significant and lasting reduction in outflows (Varvelli and Villa, 2018). Likewise, others point to the militias extending migrants' permanence in formal and informal centres in Libya as an explanation (Varvelli and Villa, 2019). Be that as it may, Italy's and the EU's actions somehow achieved the intended objective of curbing inflows, albeit at the cost of intense criticism.

The first criticism has to do with the viability of migration objectives as well as state-building goals. While coordination with the Sarraj government was clearly prioritized, the assumption that this political authority had full control of the country would be highly erroneous, given the fragmented internal political scenario. Indeed, Libya has few unitary state institutions, and those that do exist seem to exercise no substantive power. This assessment is even more complicated by the fact that the roles of different actors within the country have sometimes been dubious and prone to sudden change. This has made it more difficult to frame a clear strategy or a common policy line, balancing different interests propelled by a clear, identifiable actor. The absence of a functioning and normal state in Libya has been clearly stated: this was the factor that prompted smugglers to act undisturbed to begin with, the argument went. This element indeed might at first sight represent both a methodological and practical challenge to migration diplomacy if we assume states' strength and capacity as key to the process. However, an increasing strand of the literature has started taking into account the interaction between non-state actors and states' formal migration diplomacy aims (Malit and Tsourapas, 2021).

The peculiarity of this case is that it represents a situation in which migration-related tasks and state-building objectives have sustained and nurtured each other in the diplomatic effort. Conceptually, this uncovers a new dimension of migration diplomacy which extends to intra-state relations. While generally referring to the GNA in its rhetoric, the diplomatic efforts of Italy in particular addressed multiple actors (the GNA, municipalities, tribes and indeed, although tacitly, 
militias). A major effort in the diplomatic game, in fact, consisted of acknowledging the roles of the different actors who had a significant impact on migration dynamics, and encapsulating these actors into a predictable path towards political authority, thus reducing challenges related to reliability.

A second issue concerns the expected aims of the interaction. Reducing inflows along the central Mediterranean route does not seem to have been accompanied by the strengthening of Libyan institutions. On the contrary, the opposite has been observed, with the added impediment of the disruptive role of European and international actors, providing their support to different factions to gain more leverage on the country (Varvelli and Villa, 2018). Also, in stark contrast to the decline in migrant numbers along the central Mediterranean route, no comparable drop was registered in Libya itself in that period, and the empowerment of criminal organizations has remained constant, with migration and hydrocarbon smuggling activities nurturing and reinforcing one another (Mannocchi, 2017; Piovesana, 2017; Pradella and Cillo, 2020). Also, the recognition that militia largely profit from illicit trafficking (mainly of migrants and hydrocarbons) should have inspired a debate on how to incentivize different sources of income including how to more efficiently distribute hydrocarbon rents as part of a fair and more effective statebuilding process (Mannocchi, 2017; Varvelli and Villa, 2018). According to some scholars, the modality of co-opting militias involved in human smuggling into new governmental institutions was not only dysfunctional (Pack, 2019; Megerisi and Varvelli, 2020) but also ran contrary to the objective of political stability (Micallef and Reitano, 2017; Baldwin-Edwards and Lutterbeck, 2019; Herbert, 2019). Additionally, even though efforts have been made to address local challenges, some researchers maintain that human smuggling operates differently in different parts of the country according to varying economic and security situations (Micallef and Reitano, 2017). Understanding this would be far more helpful than any attempt at strengthening the capacities of the central government (Al Arabi, 2018). ${ }^{12}$

But the effect on migrants is the aspect of the diplomatic game that cannot be overlooked. This is both because of its negative consequences for migrants and because it plainly contradicts Italy's and the EU's narrative. Even before Gaddafi's end, EU and Italian cooperation with Libya on migration (but also on other dossiers such as hydrocarbons) had been denounced as having produced dire consequences for migrants' treatment and fate. After 2011, the situation spiralled even more out of control, with effects of displacement and increased vulnerability resulting from the consequences of the military intervention and tough European policies on irregular immigration (Pradella and Rad, 2017; Pradella and Cillo, 2020). Commentators have condemned the blatant hypocrisy of masking the objective of curbing arrivals on European shores, with the smokescreen of attempting to act on humanitarian grounds (Amnesty International, 2017; Oxfam, 2017; Baldwin-Edwards and Lutterbeck, 2019). Interdiction operations by the Libyan coast guard and the situation of detention structures (often run by militias) stand out as stark examples; and the coast guard's involvement in human smuggling has been denounced and sanctioned (Porsia, 2017; United Nations Security Council, 2017; Megerisi, 2018; Campbell and D’Agostino, 2021; Mannocchi, 2017). Meanwhile, the endorsement of militia leaders as key political actors could only diminish responsiveness to requests for human rights protection (Varvelli and Villa, 2019). The use of funds from the EU Emergency Trust Fund for migration-related objectives would be a further confirmation of the priority given first and foremost to the reduction of irregular immigration (CINI and Concord Italia, 2017; Fine and Megerisi, 2019). The strengthening of Libyan search and rescue capabilities contributed to endangering migrants' lives by bringing them back to a largely insecure situation in which protection was and is absent (UNHCR, 2019), while deployment of CSDP missions in the Mediterranean did not undermine but merely re-oriented smugglers' strategies. Had migrants' lives been the main issue at stake,

\footnotetext{
${ }^{12}$ Looking at the different political economies of irregular immigration operating in African regions, as well as the role of actors, local governance and stability/instability dynamics would be advisable if the risks of exacerbating the causes of emigration are to be avoided (Molenaar and El Kamouni-Janssen 2017).
} 
fighting smuggling would have first and foremost allowed for more legal migration opportunities in the EU, as advocated by the origin and transit countries of the Contact Group, including the resettlement of persons in need of protection (ECRE, 2018). Instead, voluntary return programmes via cooperation with sometimes disputable countries were opted for.

\section{Conclusion}

During 2017, interactions between the EU, Italy and Libya have been frequent and have largely involved migration. Following years of soaring arrivals of migrants on Italian shores, both actors have been negotiating with the north African country to lessen the flow by adopting a specific approach.

This approach, somehow conforming to UN Council Resolutions regarding the country, consisted of helping Libya to regain full control of its sovereign prerogatives after years of civil unrest. Part of this effort entailed restoring the country's capacity to control its own borders and fight human smuggling, believed to impinge on the country's unity, stability, security and development. This article has presented a case of migration diplomacy, that is, of the diplomatic use of migration to achieve goals for all actors at the negotiation table. While Italy and the EU had an evident interest in forcing the migration issue to dilute pressures on European borders, for Libya, or, better, the GNA, collaboration could mean international legitimacy, recognition and support for restoring statehood. Hence migration featured as a means and an end for the different players.

The article has also demonstrated how a triangular relationship has been at play. The EU's aims with Libya could hardly have been met through direct interaction: the Union's action could only support Italian moves, mainly financially, as the Mediterranean country had far more leverage due to its longstanding relations with Libya. At the same time though, Italy's initiatives could only be pursued against the backdrop of the Union's framework and were somehow accelerated by the lack of solidarity shown by other Member States: hence, for example, the military deployment in Libyan territorial waters took place after a series of hectic (but unsuccessful) attempts to get more money for programmes for origin and transit countries and 'regionalize' disembarkments to reduce the weight of significant arrivals. Undeniably, the diplomatic game rotating around migration was open to much criticism, questioning the viability of diplomatic talks with a loose political authority (and its implications), the accomplishments of purported objectives on both sides of the negotiation table and, chiefly, the fate of those not sitting at the table and yet bearing most of the consequences of deals reached, that is, the migrants.

The EU-Turkey Statement of 2016 has been observed as one specimen of migration diplomacy while this article has proposed a relevant second one. Yet there are many more cases to be explored to broaden the literature and go beyond available studies on the external dimension to migration: the EU-Afghanistan Joint Way Forward of 2016 or EU cooperation with Serbia and North Macedonia during the migration crisis are just two examples. Also, pertinent cases for the analysis of triangular migration diplomacy could be EU-Greece-Turkey and EUCroatia-Bosnia relations: in both cases, the EU's actions took place as part of already consolidated (although not necessarily smooth) encounters between bordering states on many levels, including migration management (Baldwin-Edwards, 2006; Geddes and Taylor, 2016). The same can be said of the more recent and intricate relations between Morocco, Spain and the EU, with a particular focus on Ceuta and Melilla (El Azzouzi and Brahim, 2021) or, to stay with Afghanistan, the recent takeover of the Taliban and forthcoming relations with the EU and neighbouring states, Pakistan foremost. The use of migration by Belarus along the border with Lithuania and Poland as a message to the EU is but another key episode worth noting. Another interesting analysis could focus on the triangular game at play between the EU, the UK and Ireland after Brexit (De Mars and Murray, 2020), also in the light of the Common 
Travel Area MOU signed in 2019; relations between the EU, UK and France are sure to be another relevant page of the Brexit dossier. And indeed, research could be extended far beyond the European radar to appreciate how migration diplomacy enters and affects international relations and vice versa: in this sense, an analysis of triangular migration diplomacy between the US, Mexico and Central America would also make a valuable contribution (Brice, 2019; Jaffe, 2021).

Funding. The research has been funded by the Jean Monnet Module 'Crises - Critical Risks for Integration and Solidarity in the European Space' 599047-EPP-1-2018-1-IT-EPPJMO-MODULE.

Data. The replication dataset is available at http://thedata.harvard.edu/dvn/dv/ipsr-risp

Acknowledgments. The author wishes to thank Enrico Fassi, Sonia Lucarelli, Giorgio Grappi, Ferruccio Pastore, Arturo Varvelli and Matteo Villa for their valuable suggestions and two anonymous reviewers for their comments on an earlier version of this work.

\section{References}

Adamson FB and Tsourapas G (2019) Migration diplomacy in world politics. International Studies Perspectives 20, $113-128$.

Al Arabi A (2018) Local specificities of migration in Libya: challenges and solutions. Policy Briefs, 2018/04, European University Institute. Available at https://cadmus.eui.eu/handle/1814/52585.

Amnesty International (2017) Libya's dark web of collusion: abuses against Europe-bound refugees and migrants. Amnesty International. Available at https:/www.amnesty.org/en/documents/mde19/7561/2017/en/.

Baldwin-Edwards M (2006) Migration between Greece and Turkey: from the 'exchange of populations' to the nonrecognition of borders. SEER: Journal for Labour and Social Affairs in Eastern Europe 9, 115-122.

Baldwin-Edwards M and Lutterbeck D (2019) Coping with the Libyan migration crisis. Journal of Ethnic and Migration Studies 45, 2241-2257.

Beach D (2017) Process-tracing methods in social science. In Thompson WR (ed.), Oxford Research Encyclopedias of Politics: Qualitative Political Methodology. Oxford: Oxford University Press. https://doi.org/10.1093/acrefore/9780190228637.013. 176.

Betts A (2010) Substantive issue-linkage and the politics of migration. In Bjola C and Kornprobst M (Eds), Arguing Global Governance. Abingdon: Routledge, pp. 85-100.

Betts A (2011) International cooperation in the refugee regime. In Betts A and Loescher G (Eds), Refugees in International Relations. Oxford: Oxford University Press, pp. 53-84.

Boswell C (2003) The 'external dimension' of EU immigration and asylum policy. International Affairs 79, 619-638.

Brice M (2019) Trump threatens more tariffs on Mexico over part of immigration deal. Reuters. Available at https://www. reuters.com/article/us-usa-trade-mexico-idUSKCN1TB182 (accessed 23 February 2021).

Campbell Z and D'Agostino L (2021) Friends of the traffickers. The Intercept, 30 April, Available at https://theintercept.com/ 2021/04/30/italy-anti-mafia-migrant-rescue-smuggling/ (accessed 22 May 2021).

Carrera S (2016) Implementation of EU Readmission Agreements: Identity Determination Dilemmas and the Blurring of Rights. Switzerland: Springer.

Cassarino JP (2010) Readmission policy in the European Union. European Parliament. Available at https://op.europa.eu/en/ publication-detail/-/publication/b8111d18-cbfc-4d72-8554-d85e86b0eff3/language-en.

Cassarino JP (2018) Informalizing EU readmission policy. In Trauner F and Ripoll Servant A (Eds), The Routledge Handbook of Justice and Home Affairs Research. Abingdon: Routledge, pp. 83-98.

Cazzullo A (2017) Solidarietà nazionale per combattere terroristi e trafficanti di uomini. Corriere della Sera, 3 October. Available at https://www.corriere.it/politica/17_settembre_30/minniti-solidarieta-nazionale-contro-terroristi-trafficantiuomini-a5e807b2-a605-11e7-8477-789085dabc53.shtml (accessed 1 February 2020).

Ceccorulli M (2014) Framing irregular immigration in security terms. The case of Libya. Firenze: Firenze University Press.

Ceccorulli M and Coticchia F (2015) Multidimensional threats and military engagement: the case of the Italian intervention in Libya. Mediterranean Politics 20, 303-321.

Ceccorulli M and Coticchia F (2020) 'I'll take two.' Migration, terrorism, and the Italian military engagement in Niger and Libya. Journal of Modern Italian Studies 25, 174-196.

Central Mediterranean Contact Group (2017a) Dichiarazione d'intenti. Rome, 20 March. Available at https://www.interno. gov.it/sites/default/files/allegati/cmcg.pdf (accessed 23 January 2021).

Central Mediterranean Contact Group (2017b) Déclaration de Tunis. Tunis, 24 July. Available at https://www.europarl.europa.eu/doceo/document/E-8-2017-004743-ASW_EN.html (accessed 11 January 2021). 
Coleman N (2009) European Readmission Policy: Third Country Interests and Refugee Rights. Leiden: Martinus Nijhoff Publishers.

Collet E and Ahad A (2017) EU migration partnerships: a work in progress. Migration Policy Institute Europe. Available at https://www.migrationpolicy.org/sites/default/files/publications/TCM-EUMigrationPartnerships-FINAL.pdf.

Cusumano E (2017) Straightjacketing migrant rescuers? The code of conduct on maritime NGOs. Mediterranean Politics 24, 106-114.

Darme MC and Benattia T (2017) Mixed migration trends in Libya: changing dynamics and protection challenges. Report for the UNHCR by ALTAI Consulting and IMPACT. Available at https://www.unhcr.org/publications/operations/ 595a02b44/mixed-migration-trends-libya-changing-dynamics-protection-challenges.html.

De Mars and Murray C (2020) With or without EU? The common travel area after Brexit. German Law Journal 21, 815-837.

Demiryontar B (2020) Accession conditionality and migration diplomacy: Turkey's dual identity in migration policy negotiations with the EU. European Politics and Society 22, 88-103.

Düvell F (2017) The EU's international relations and migration diplomacy at times of crisis: key challenges and priorities. Perceptions 22, 35-54.

ECRE (2018) Beyond Europe. Libya: returning operations running but slow resettlement is jeopardizing the evacuation scheme. ECRE Weekly Bulletin. Available at https://www.ecre.org/libya-return-operations-running-but-slow-resettlement-is-jeopardizing-the-evacuation-scheme/.

El Azzouzi R and Brahim N (2021) Entre le Maroc et l'Espagne, 'il faut sortir de cette dramatization de la frontière'. Mediapart, 19 May. Available at https://www.mediapart.fr/journal/international/190521/entre-le-maroc-et-l-espagne-ilfaut-sortir-de-cette-dramatisation-de-la-frontiere (accessed 22 May 2021).

Elbagir N, Razek R, Platt A and Jones B (2017) People for sale. CNN, 14 November. Available at https://edition.cnn.com/ 2017/11/14/africa/libya-migrant-auctions/index.html (accessed 1 February 2020).

Engelbrekt K, Mohlin M and Wagnsson C (Eds) (2013) The NATO Intervention in Libya: Lessons Learned from the Campaign. New York: Routledge.

European Commission (2015a) A European Agenda on migration. COM(2015) 240 final. Available at https://ec.europa.eu/ home-affairs/what-we-do/policies/new-pact-on-migration-and-asylum_en.

European Commission (2015b) Review of the European Neighbourhood Policy. JOIN (2015) 50 final. Available at https://ec. europa.eu/neighbourhood-enlargement/tenders/consultation_en_en.

European Commission (2015c) On the establishment of a European Union Emergency Trust Fund for stability and addressing the root causes of irregular migration and displaced persons in Africa. COM(2015) 7293 final. Available at https://ec. europa.eu/transparency/documents-register/detail?ref=C(2015)7293\&lang=it.

European Commission (2016) On establishing a New Partnership Framework with third countries under the European Agenda on migration. $\operatorname{COM}(2016) 385$ final. Available at https://eur-lex.europa.eu/resource.html?uri=cellar:763f0d112d86-11e6-b49701aa75ed71a1.0001.02/DOC_1\&format=PDF.

European Commission (2017a) Migration on the Central Mediterranean Route. Managing flows, saving lives. JOIN (2014) 4 final. Available at https://ec.europa.eu/home-affairs/sites/default/files/what-we-do/policies/european-agenda-migration/ proposal-implementationpackage/docs/20170125_migration_on_the_central_mediterranean_route_-_managing_flows_saving lives_en.pdf.

European Commission (2017b) EU Trust Fund for Africa adopts E90 million programme on protection of migrants and improved migration management in Libya. Press Release. Available at https:/ec.europa.eu/commission/presscorner/ detail/en/IP_17_951.

European Commission (2017c) For a renewed impetus of the Africa-EU Partnership. JOIN (2017) 17 final. Available at https://eur-lex.europa.eu/legal-content/EN/TXT/PDF/?uri=CELEX:52017JC0017\&from=EN.

European Commission (2017d) Action plan on measures to support Italy, reduce pressure along the Central Mediterranean route and increase solidarity. SEC(2017) 339. Available at https://ec.europa.eu/home-affairs/sites/default/files/what-we-do/ policies/european-agenda-migration/20170704_action_plan_on_the_central_mediterranean_route_en.pdf.

European Commission (2017e) Fifth progress report on the Partnership Framework with third countries under the European Agenda on Migration. COM (2017) 471 final. Available at https://ec.europa.eu/home-affairs/sites/default/files/ what-we-do/policies/european-agenda-migration/20170906_fifth_progress_report_on_the_partnership_framework_with_ third_countries_under_the_eam_en.pdf.

European Council (2015a) Council decision (CFSP)2015/778 of 18 May 2015 on a European Union military operation in the Southern Central Mediterranean (EUNAVFOR MED). Available at https://eur-lex.europa.eu/legal-content/EN/TXT/PDF/? uri=CELEX:32015D0778\&from $=$ EN.

European Council (2015b) Valletta Summit, 11-12 November 2015. Action Plan. Available at https://www.consilium.europa. eu/media/21839/action_plan_en.pdf.

European Council (2016) EUBAM Libya: mission extended, budget approved. Press Release. Available at https://www.consilium.europa.eu/en/press-releases-pdf/2016/8/47244645239_en.pdf/.

European Council (2017a) EUBAM Libya Initial Mapping Report Executive Summary. 5616/17. Available at https://www. statewatch.org/media/documents/news/2017/feb/eu-eeas-libya-assessment-5616-17.pdf. 
European Council (2017b) Malta declaration by the Members of the European Council on the External Aspects of Migration: addressing the Central Mediterranean route. Press Release. Available at https://www.consilium.europa.eu/en/press/pressreleases/2017/02/03/malta-declaration/.

European Council (2017c) Joint declaration of 5th African Union-European Union Summit. Available at https://www.consilium.europa.eu/media/31991/33454-pr-final_declaration_au_eu_summit.pdf.

European External Action Service (2014) Libya, a Political Framework for a Crisis Approach. 13829/14. Available at https:// www.statewatch.org/media/documents/news/2014/nov/eu-council-libya.pdf.

European External Action Service (2017a) A strategic approach to resilience in the EU's external action. JOIN (2017)21 final. Available at https://eur-lex.europa.eu/legal-content/EN/TXT/PDF/?uri=CELEX:52017JC0021\&from=en.

European External Action Service (2017b) Meeting of the Joint AU-EU-UN Taskforce to address the migrant situation in Libya. Press Release. Available at https://eeas.europa.eu/headquarters/headquarters-homepage_en/37401/Meeting\%20of\% 20the\%20Joint\%20 AU-EU-UN\%20Taskforce\%20to\%20Address\%20the\%20Migrant\%20Situation\%20in\%20Libya.

Fernández-Molina I and De Larramendi MH (2020) Migration diplomacy in a de facto destination country: Morocco's new intermestic migration policy and international socialization by/with the EU. Mediterranean Politics, published early online 27 May 2020. Available at https://www.tandfonline.com/doi/abs/10.1080/13629395.2020.1758449.

Fine S and Megerisi T (2019) The unacknowledged costs of the EU's migration policy in Libya. Commentary, ECFR. Available at https://ecfr.eu/article/commentary_unacknowledged_costs_of_the_eu_migration_policy_in_libya/.

Frowd PM (2020) Producing the 'transit' migration state: international security intervention in Niger. Third World Quarterly 41, 340-358.

Geddes A and Taylor A (2016) In the shadow of Fortress Europe? Impacts of European migration governance on Slovenia, Croatia and Macedonia. Journal of Ethnic and Migration Studies 42, 587-605.

Governo Italiano (2017a) Memorandum d'intesa sulla cooperazione nel campo dello sviluppo, del contrasto all'immigrazione illegale, al traffico di esseri umani, al contrabbando e sul rafforzamento della sicurezza delle frontiere tra lo Stato della Libia e la Repubblica Italiana. Available at https://www.governo.it/sites/governo.it/files/Libia.pdf.

Governo Italiano (2017b) Dichiarazione congiunta. Affrontare la sfida della migrazione e dell'asilo politico. Available at https://www.governo.it/sites/governo.it/files/documenti/documenti/Notizie-allegati/governo/Parigi_20170828/dichiarazione_congiunta_20170828.pdf.

Greenhill KM (2010) Weapons of Mass Migration: Forced Displacement, Coercion and Foreign Policy. Ithaca, NY: Cornell University Press.

Greenhill KM (2016) Migration as a weapon in theory and practice, Military Review, November-December, pp. 23-36.

Haas E (1980) Why collaborate? Issue-linkage and international regimes. World Politics 32, 357-405.

Hampshire J (2016) Speaking with one voice? The European Union's global approach to migration and mobility and the limits of international migration cooperation. Journal of Ethnic and Migration Studies 42, 571586.

Herbert M (2019) Less than the sum of its parts. Policy Brief 126, ISS Institute for Security Studies. Available at https://issafrica.org/research/policy-brief/less-than-the-sum-of-its-parts-europes-fixation-with-libyan-border-security.

İçduygu A and Aksel DB (2014) Two-to-tango in migration diplomacy: negotiating readmission agreement between the EU and Turkey. European Journal of Migration and Law 16, 337-363.

Jaffe A (2021) Mexico, Honduras, Guatemala deploy troops to lower migration. Associated Press, 13 April. Available at https://apnews.com/article/guatemala-honduras-mexico-immigration-border-patrols-917c0fea87c0a807b371da207d34c8cc (accessed 11 May 2021).

Koch A, Weber A and Werenfels I (Eds) (2018) Profiteers of migration? Authoritarian States in Africa and European Migration Management. SWP Research Paper 4. Available at https://www.swp-berlin.org/fileadmin/contents/products/ research_papers/2018RP04_koh_et_al.pdf.

Kratochwil FV and Mansfield ED (1994) International Organization and Global Governance: A Reader. London: PearsonLongman.

Kuperman A (2013) A model humanitarian intervention? Reassessing NATO’s Libya campaign. International Security 38, $105-136$.

Lavenex S and Kunz R (2008) The migration-development nexus in EU external relations. Journal of European Integration 30, 439-457.

Longo G (2017) Libia, le tribù del Sud siglano la pace e si impegnano a bloccare i migranti. La Stampa, 2 April. Available at https://www.lastampa.it/2017/04/02/esteri/libia-le-trib-del-sud-siglano-la-pace-e-si-impegnano-a-bloccare-i-migrantiqZNs23DGe0OSdJi7G285FK/pagina.html (accessed 6 February 2020).

Ludovico M (2017a) Minniti rilancia con la Libia: il 13 vede i Sindaci. Il Sole 24 Ore, 7 July. Available at https://www.ilsole24ore.com/art/mondo/2017-07-07/minniti-rilancia-la-libia-13-vede-sindaci-063657.shtml?uuid=AEPAWWtB (accessed 1 February 2020).

Ludovico M (2017b) La Libia chiede navi militari italiane. Il Sole 24 Ore, 14 July. Available at https://www.ilsole24ore.com/ art/notizie/2017-07-14/la-libia-chiede-navi-militari-italiane-063837.shtml?uuid=AEFcgGxB (accessed 1 February 2020). 
Maggie M (2017) Backed by Italy, Libya enlists militias to stop migrants. Associated Press, 29 August. Available at https:// apnews.com/article/9e808574a4d04eb38fa8c688d110a23d (accessed 11 February 2021).

Malit FT and Tsourapas G (2021) Migration diplomacy in the Gulf - non-state actors, cross-border mobility and the United Arab Emirates. Journal of Ethnic and Migration Studies 47, 2556-2577.

Mannocchi F (2017) Italy accused of bribing Libyan militias to stop migrants reaching Europe. Middle East Eye, 26 August. Available at https://www.middleeasteye.net/news/italy-accused-bribing-libyan-militias-stop-migrants-reaching-europe

Megerisi T (2018) Mr Salvini goes to Tripoli. Commentary, ECFR. Available at https://ecfr.eu/article/ commentary_mr_salvini_goes_to_tripoli/.

Megerisi T and Varvelli A (2020) Italy's chance in Libya. Commentary, ECFR. Available at https://ecfr.eu/article/ commentary_italys_chance_in_libya/.

Micallef M and Reitano T (2017) The anti-human smuggling business and Libya's political endgame. North Africa Report 2, Institute for Security Studies. Available at https:/globalinitiative.net/wp-content/uploads/2018/01/Libya_ISS_Smuggling. pdf.

Ministero dell'Interno (2017a) Chi vuole continuare le azioni di salvataggio deve firmare il codice. La Stampa. Available at http://www.interno.gov.it/it/sala-stampa/interventi-e-interviste/chi-vuole-continuare-azioni-salvataggio-deve-firmare-codice (accessed 1 February 2020).

Ministero dell'Interno (2017b) Migranti, il Gruppo di contatto per la rotta del Mediterraneo centrale diventa stabile. Available at https://www.interno.gov.it/it/notizie/migranti-gruppo-contatto-rotta-mediterraneo-centrale-diventa-stabile.

Molenaar F and El Kamanoui-Janssen F (2017) Turning the tide. The politics of irregular immigration in the Sahel and Libya. CRU Report, Institute of International Relations Clingendael. Available at https://www.clingendael.org/sites/ default/files/pdfs/turning_the_tide.pdf.

Morone AM (2017) Policies, practices, and representations regarding Sub-Saharan migrants in Libya: from the partnership with Italy to the Post-Qadhafi Era. In Gaibazzi P, Dünnwald S and Bellagamba A (eds), EurAfrican Borders and Migration Management. Palgrave Series in African Borderlands Studies. New York: Palgrave Macmillan, pp. $129-155$.

Norman KP (2020) Migration diplomacy and policy liberalization in Morocco and Turkey. International Migration Review 54, 1158-1183.

Oxfam International (2017) Press release: EU-Libya plans shine spotlight on European Duplicity. Available at https://www. oxfam.org/en/press-releases/eu-libya-plans-shine-spotlight-european-duplicity.

Pack J (2019) Kingdom of Militias: Libya's second war of Post-Qadhafi Succession. Analysis, ISPI. Available at https://www. ispionline.it/it/pubblicazione/kingdom-militias-libyas-second-war-post-qadhafi-succession-23121.

Paoletti E (2010) The Migration of Power and North-South Inequalities, The Case of Italy and Libya. London: Palgrave Macmillan.

Pastore F (2017) Migration policy. Beyond containment. Aspenia International 76, 71-81.

Pastore F and Roman E (2020) Migration policies and threat-based extraversion. Analysing the impact of European externalisation policies on African polities. Revue Européenne des Migrations Internationals 36, 133-152.

Piovesana E (2017) Gli scafisti e la protezione alla Joint Venture dell'Eni. Il Fatto Quotidiano, 9 May. Available at https:// www.ilfattoquotidiano.it/in-edicola/articoli/2017/05/09/gli-scafisti-e-la-protezione-alla-joint-venture-delleni/3571746/ (accessed 22 April 2020).

Porsia N (2017) The kingpin of Libya's human trafficking mafia. TRT World, 20 February. Available at https://www.trtworld. com/magazine/libya-human-trafficking-mafia-in-zawiya-301505 (accessed 24 May 2021).

Pradella L and Cillo R (2020) Bordering the surplus population across the Mediterranean: imperialism and unfree labour in Libya and the Italian countryside. Geoforum; Journal of Physical, Human, and Regional Geosciences. https://doi.org/10. 1016/j.geoforum.2020.06.019.

Pradella L and Rad ST (2017) Libya and Europe: imperialism, crisis and migration. Third World Quarterly 38, $2411-2427$.

Seeberg P (2020) Syrian refugees in Jordan and their integration in the labour market: Jordanian migration diplomacy and EU incentives. Mediterranean Politics, published early online 27 May 2020. Available at https://www.tandfonline.com/doi/ abs/10.1080/13629395.2020.1758452.

Senato della Repubblica (2017) Nuove missioni internazionali. $17^{\circ}$ Legislatura.

Thiollet H (2011) Migration as diplomacy: labor migrants, refugees, and Arab regional politics in the oil-rich countries. International Labor and Working-Class History 79, 103-121.

Tsourapas G (2017) Migration diplomacy in the Global South: cooperation, coercion and issue linkage in Gaddafi's Libya. Third World Quarterly 38, 2367-2358.

Tsourapas G (2019) The Syrian refugee crisis and foreign policy decision-making in Jordan, Lebanon and Turkey. Journal of Global Security Studies 4, 464-481.

UNHCR (2019) Mixed migration routes and dynamics in Libya, May-December 2018. REACH Resource Centre. Available at https://reliefweb.int/sites/reliefweb.int/files/resources/impact_lby_report_mixed_migration_routes_and_dynamics_in_2018_ june_2019.pdf. 
United Nations Security Council (2017) Letter dated 1 June 2017 from the Panel of Experts on Libya established pursuant to resolution 1973 (2011) addressed to the President of the Security Council. Available at https://reliefweb.int/sites/reliefweb. int/files/resources/N1711623.pdf.

United Nations Support Mission (2016) “Detained and Dehumanised”. Report on Human Rights Abuses against Migrants in Libya. 13 December.

Varvelli A and Villa M (2018) La Libia tra conflitto e migranti: ripensare il ruolo delle milizie, ISPI Policy Brief. Available at https://www.ispionline.it/it/pubblicazione/la-libia-tra-conflitto-e-migranti-ripensare-il-ruolo-delle-milizie-21012.

Varvelli A and Villa M (2019) Italy's Libyan conundrum: the risk of short-term thinking. Commentary, ECFR. Available at https://www.ispionline.it/it/pubblicazione/italys-libyan-conundrum-risks-short-term-thinking-24469.

Völkel JC (2020) Fanning fears, winning praise: Egypt's smart play on Europe's apprehension of more undocumented immigration. Mediterranean Politics, published early online 27 May 2020, Available at https://www.tandfonline.com/doi/abs/10. 1080/13629395.2020.1758450?journalCode=fmed20.

Woollard C (2018) Editorial: Egypt plays the migration game. ECRE. Available at https://www.ecre.org/editorial-egypt-playsthe-migration-game/.

Yildiz AG (2016) The European Union Immigration Policy. Managing Migration in Turkey and Morocco. London: Palgrave Macmillan.

Cite this article: Ceccorulli M (2022). Triangular migration diplomacy: the case of EU-Italian cooperation with Libya. Italian Political Science Review/Rivista Italiana di Scienza Politica 52, 328-345. https://doi.org/10.1017/ipo.2021.47 